\title{
Activation of Immune Cells in Bovine Mammary Gland Secretions by Zymosan-Treated Bovine Serum ${ }^{1}$
}

\author{
K. Kimura, ${ }^{2}$ J. P. Goff, M. J. Schmerr, J. R. Stabel, ${ }^{3}$ S. Inumaru, ${ }^{4}$ and Y. Yokomizo ${ }^{4}$ \\ USDA, Agricultural Research Service, National Animal Disease Center, Periparturient Diseases of Cattle Research Unit, Ames, IA 50010-0070
}

\begin{abstract}
Mastitis, caused by bacterial infection of the mammary gland, is a major disease of dairy cattle. The greatest risks of intramammary infection occur at the end of lactation and at the initiation of the next lactation when the cow calves. Treating serum with zymosan (yeast cell wall preparation) causes the complement to cleave, allowing this serum to serve as a source of complement fragment 5a (C5a), a potent chemoattractant and activator of the immune system. Our hypothesis was that intramammary infusion of zymosantreated serum (ZTS) would recruit polymorphonuclear neutrophils (PMN) and generate prolonged activity in lymphocytes within the mammary gland. Ultimately this could help prevent bacterial infections in cows at dry-off and at the initiation of lactation. Two ipsilateral quarters of the mammary gland of each cow were infused with ZTS (12.5 mL/quarter), and 2 contralateral quarters were infused with saline in 8 cows shortly after lactation ended. Mammary secretions were collected periodically throughout the dry period and the first 2 wk of the next lactation. Activation status of lymphocytes and PMN in those secretions was assessed based on the intracellular presence or absence of IFN- $\gamma$ and IL-8 as determined by flow cytometry. The ZTS infusion greatly increased PMN numbers in mammary secretions for the first week only. The percentage of IFN- $\gamma$ positive lymphocytes and PMN, and the percentage of IL-8 positive PMN, exhibited a sustained increase in secretions from ZTS-treated quarters through the first 2 wk of lactation. The ZTS can stimulate PMN and lymphocyte-mediated immune defense mechanisms in the mammary gland, which may provide a useful means
\end{abstract}

\footnotetext{
Received November 26, 2007.

Accepted January 18, 2008.

${ }^{1}$ Names are necessary to report factually on available data; however, the USDA neither guarantees nor warrants the standard of the product, and the use of the name by USDA implies no approval of the product to the exclusion of others that may also be suitable.

${ }^{2}$ Corresponding author: kimurakayoko@msn.com

${ }^{3}$ Bacterial Diseases of Livestock Research Unit.

${ }^{4}$ National Institute of Animal Health, Tsukuba, Japan.
}

of preventing new intramammary infections during the dry period as well as at the initiation of lactation.

Key words: complement, dairy cow, interleukin-8, mastitis

\section{INTRODUCTION}

The mammary gland of a dairy cow is particularly susceptible to infection at the cessation of lactation and again at the onset of the next lactation. The highest susceptibility to infection during dry off occurs the first 2 wk of the dry period, which can be attributed to several factors. For instance, cessation of milking causes a build-up of pressure at the teat end within a few days of dry-off, which can prevent full closure of the teat orifice, allowing an open avenue for bacterial invasion (Cousins et al., 1980; Comalli et al., 1984). During lactation, regular milk removal helps flush bacteria from the teat canal before they can colonize the ductal epithelium. Also, when cows are milked regularly, the teat ends are generally kept clean and dipped regularly with disinfectant, keeping bacterial populations at the teat end low. At dry-off the teat end is not disinfected regularly and the milk at the teat end is not being removed. Over time, a keratin plug is formed at the teat end, effectively blocking bacterial invasion, but this may require more than 1 wk to form, and until it is formed the cow is at risk for infection (Cousins et al., 1980). As the cow approaches parturition she is again at increased risk of IMI. The udder often swells with colostral secretions, which may be further complicated by udder edema in some animals. Again the teat canal is shortened, as a result of the internal pressure building up in the teat cistern, and the teat end becomes dilated. The keratin plug often begins to break down within 7 to $10 \mathrm{~d}$ of calving. The cow faces another situation where the teat orifice may be open in less than sanitary conditions before calving (Smith et al., 1985).

The most active phagocytic cell in milk is polymorphonuclear neutrophils (PMN). The PMN serve as the first line of immune-mediated defense against IMI because they can kill opsonized and nonopsonized bacteria using bactericidal enzymes and oxygen derived free radicals (Nickerson, 1989; Paape et al., 2000). Recruiting more 
PMN, the first line of defense, into the mammary gland at dry-off using proinflammatory substances has been done using substances such as endotoxin (Oliver and Smith, 1982a), colchicine (Oliver and Smith, 1982b,c), and oyster glycogen (Paape et al., 1976; Guidry et al., 1980). These studies were focused on acceleration of involution to reduce intracisternal pressure, increase lactoferrin content of mammary secretions, and recruit PMN to help eliminate infections during the early portion of the dry period. In general these agents successfully reduced the susceptibility of the gland to new IMI during the first week of the dry period. The few studies examining the long-term effect of these compounds did not show a beneficial effect on the incidence of new infections late in the dry period or in early lactation (Oliver and Smith, 1982c). These studies generally did not examine any effects these treatments might have had on lymphocytes and their functional status. These treatments were also associated with induction of transient but high fever in many animals and, in some cases, a reduction in milk production at the next lactation.

Treating bovine serum with zymosan, a refined extract of Saccharomyces cerevisiae containing $\beta 1,3 \mathrm{D}-$ glucan, causes cleavage of complement within the serum. This serum can then serve as a crude source of complement fragment $\mathrm{C} 5 \mathrm{a}$, a potent activator and chemoattractant of immune cells (Rainard et al., 1998; Rainard, 2003). The C5a can recruit and activate PMN, which is an attribute shared by the compounds previously studied as a mean to accelerate involution of the mammary gland. However, C5a is also capable of activating antigen presenting cells (macrophage, B cells) and T cells (Morgan et al., 1983; Tsuji et al., 1997; Nielsen and Leslie, 2002). Recently C5a has been applied as an adjuvant to stimulate formation of longlasting activated lymphocytes (Ulrich et al., 2000; Sanderson et al., 2003). We hypothesized that intramammary infusion of zymosan-treated serum (ZTS) just after cessation of lactation would recruit and activate both PMN and lymphocytes. Ultimately, it may be possible to generate these activated cells and maintain them within mammary secretions throughout the dry period and early lactation. They can then go on to recruit/activate other lymphocytes and PMN through more secretion of cytokines, should they encounter bacterial antigens they recognize.

To test this hypothesis, 2 of the 4 quarters of the mammary gland of dairy cows were infused with ZTS (12.5 mL/quarter) and the other 2 quarters with physiological saline in 8 cows shortly after lactation ended. Mammary gland secretions were collected periodically throughout the dry period and for the first 2 wk of the next lactation. Lymphocytes and PMN in those secretions were considered to be activated if they were pro- ducing IFN- $\gamma$ or IL-8, which was assessed by flow cytometry.

\section{MATERIALS AND METHODS}

\section{Animals}

Eight Holstein cows in their second pregnancy were used when they were completely dried off ( 2 to $3 \mathrm{wk}$ after finishing their first lactation). This time point was chosen to insure that cows had gotten past the early dry period free of infection without dry cow therapy. No bacteria were detected in any mammary gland secretions collected during the week before this experiment or in secretions collected the day of infusion as assessed by aerobic culture of secretion samples on blood agar plates. Physiological saline or ZTS was infused into both quarters in the right half of the udder or both quarters in the left half of the udder at a dose of 12.5 $\mathrm{mL} /$ quarter. The volume of ZTS used was determined in preliminary studies performed on lactating cows to increase milk SCC to more than $10^{6} / \mathrm{mL}$ (data not shown). Induction of this number of somatic cells was formerly reported to be an effective means of reducing IMI by bacteria (Schultze and Paape, 1983). Rectal temperature was recorded at 0,7 , and $24 \mathrm{~h}$ after infusion of ZTS and saline.

All animal-related procedures conducted during this study were approved by the Animal Care and Use Committee of the USDA-ARS-National Animal Disease Center.

\section{Sampling}

All samplings of mammary secretions were performed at $0700 \mathrm{~h}$ except on the day of calving. Dry cow secretions were obtained separately from each quarter before infusion $(0 \mathrm{~d})$ and at $24 \mathrm{~h}, 8 \mathrm{~d}$, and $15 \mathrm{~d}$ after infusion. About $50 \mathrm{~mL}$ or less secretion was obtained during dry-off. When cows exhibited a noticeable increase in udder size, a precalving sample was obtained. A few cows did not calve within $7 \mathrm{~d}$, and a second sample was taken as the precalving sample. All precalving samples were obtained within 3 to $6 \mathrm{~d}$ of calving. On the day of calving, milk samples were obtained within 12 $\mathrm{h}$ after calving. Cows were milked twice a day using a quarter milker to measure milk yield separately in right and left udder halves. Milk samples (50 mL/quarter) from the 2 quarter samples from each half of the udder obtained on 0,8 , and $15 \mathrm{~d}$ after calving were combined, and an aliquot was preserved with bronopol for SCC determination. Determination of somatic cell numbers in each sample was measured by a commercial milk analysis laboratory (AgSource Milk Analysis Lab, Menomonie, WI). About $1 \mathrm{~mL}$ of mammary gland secretion 
was obtained aseptically from each quarter for bacteria culture before milking. Bacteriologic analysis was performed on all milk samples by plating $100 \mu \mathrm{L}$ of each milk sample on trypticase soy agar with $5 \%$ sheep blood (Becton Dickinson, Sparks, MD). Plates were incubated aerobically for $24 \mathrm{~h}$ at $39^{\circ} \mathrm{C}$ and the presence of colonies was determined.

\section{Preparation of Zymosan-Treated Serum}

The ZTS was prepared as previously described (Roth and Kaeberle, 1981). To use the same quality of ZTS in all cows, a single large batch of ZTS was prepared using mixed serum from 20 healthy cows ( 11 Holstein and 9 Jersey cows). The ZTS was frozen in 50-mL aliquots at $-80^{\circ} \mathrm{C}$ until use. The C5a content as determined by ELISA was $1.4 \mu \mathrm{g} / \mathrm{mL}$ (Rainard et al., 1998). Endotoxin content was measured using the Limulus amebocyte lysate test (E-TOXATE, Sigma, St. Louis, $\mathrm{MO}$ ) and confirmed to be less than $0.5 \mathrm{EU} / \mathrm{mL}$.

\section{Intracellular Cytokine Analysis by Flow Cytometry}

Milk (or dry cow secretion) samples were centrifuged at $550 \times \mathrm{g}$ for $15 \mathrm{~min}$, and the top layer was aspirated down to 5 to $10 \mathrm{~mL}$ to remove as much of the cream fat layer as possible. Then PBS was added to bring the volume back up to $50 \mathrm{~mL}$, and the sample was mixed vigorously to wash the cells. Following a second centrifugation at $500 \times g$ for $10 \mathrm{~min}$, the supernatant was removed by aspiration. Cell pellets were resuspended with 1 to $2 \mathrm{~mL}$ of PBS, dependent on pellet size.

Fifty microliters of cell suspension was incubated with $50 \mu \mathrm{L}$ each of primary mAb against CD4 (GC50A1, mouse IgM, $14 \mu \mathrm{L} / \mathrm{mL}$ ), G1 (CH138A, mouse IgM, 3.5 $\mu \mathrm{L} / \mathrm{mL}$ ), or CD45 (CACTB51A, mouse $\operatorname{IgG}_{2 \mathrm{a}}, 3.5 \mu \mathrm{L} /$ $\mathrm{mL}$ ) for $15 \mathrm{~min}$ at room temperature in a microtiter plate (U-bottom, 96-well). These mAb were obtained from VMRD Inc. (Pullman, WA), prepared in PBS with $1 \%$ fetal bovine serum, and are all specific to bovine markers (Davis et al., 1987; Bensaid and Hadam, 1991; Sager et al., 1997). Following centrifugation at $800 \times g$ for $2 \mathrm{~min}$ the supernatant was decanted. Cells were washed once with $200 \mu \mathrm{L} /$ well of PBS with $1 \%$ fetal bovine serum, centrifuged, and decanted. Following addition of $50 \mu \mathrm{L}$ of each of the secondary Ab [fluorescein isothiocyanate-conjugated goat anti-mouse IgM (100 $\mu \mathrm{L} / 25 \mathrm{~mL}$ of PBS, SouthernBiotech, Birmingham, AL), or peridinin chlorophyll protein conjugated rat antimouse $\operatorname{IgG}_{2 \mathrm{a}+\mathrm{b}}(1 \mathrm{~mL} / 11 \mathrm{~mL}$ in PBS; both from BD Biosciences Pharmingen, San Diego, CA)], the cells were incubated at room temperature in the dark for 7.5 to $10 \mathrm{~min}$. The cells were washed with PBS with $1 \%$ fetal bovine serum and fixed by exposure to $25 \mu \mathrm{L} /$ well of fixation medium (Caltag Laboratory, Burlingame, CA) for $15 \mathrm{~min}$ at room temperature in the dark. Cells were then washed with PBS with $1 \%$ fetal bovine serum once and suspended in $100 \mu \mathrm{L}$ of Permeabilization Medium (Caltag Laboratory). Phycoerythrin conjugated antibody [10 $\mu \mathrm{L}$ of mAb against IFN- $\gamma(27.6 \mu \mathrm{g} / \mathrm{mL}$; Caltag Laboratories) or against IL-8 (10 $\mu \mathrm{g} / \mathrm{mL}$; BD Biosciences Pharmingen)] was added immediately to bind and stain intracellular cytokines. The anticytokine mAb were produced against human cytokines and were mouse $\operatorname{IgG}_{1}$. Specificity studies were conducted before use to confirm that these mAb did cross-react with bovine cytokines by Western blotting. Phycoerithrin conjugated isotype control $\mathrm{Ab}$ (mouse $\mathrm{IgG}_{1}, 27.6 \mu \mathrm{g} / \mathrm{mL}$; BD Biosciences Pharmingen, San Diego, CA) was added to similarly prepared wells of cells to allow measurement of background staining. Cells were incubated with these antibodies for $15 \mathrm{~min}$ at room temperature in the dark. Cells were washed with PBS with $1 \%$ fetal bovine serum twice and resuspended in $200 \mu \mathrm{L}$ of PBS with $1 \%$ fetal bovine serum. A cell suspension from each well was then run through the flow cytometer to detect forward and side scatter of light and fluorescence of cells (LSR, BD Biosciences, San Diego, CA). Data from 20,000 events/sample were acquired. Data analysis was performed using the Cell Quest (BD Biosciences) flow cytometry software package. Mononuclear cell populations (nonG1-positive cells) and PMN populations (G1positive cells) were analyzed separately within the CD45 positive cells (leukocytes). Cytokine (IFN- $\gamma$ or IL8) positive cell numbers were expressed as a percentage within each population.

\section{Confirmation of IFN- $\gamma$ Production by Bovine PMN}

Heparinized whole blood samples taken from 2 healthy cows (untreated cows that were separate from animals used for this study) were centrifuged, and plasma was harvested and the buffy coat was removed. The remaining sediment consisting of red blood cells and PMN was hemolyzed using hypotonic phosphatebuffered deionized water and restored to isotonicity with hypertonic phosphate-buffered 2.7\% NaCl (Roth and Kaeberle, 1981). This hemolytic procedure was repeated one more time. Cells were placed on Percoll (s.d. = 1.077) and a density gradient formed by centrifuging at $800 \times g$ for $40 \mathrm{~min}$. The PMN layer was isolated and washed with PBS. Isolated PMN were enumerated and then resuspended in autologous plasma to a concentration of $1 \times 10^{7} \mathrm{PMN} / \mathrm{mL}$. The purity of PMN was confirmed by flow cytometry. The PMN suspension in plasma was divided into 2 tubes per sample. The PMN 
in one tube were stimulated to produce cytokines by adding CD3 $\mathrm{mAb}(1 \mu \mathrm{g} / \mathrm{mL}, \mathrm{VMRD})$ and goat antibody against mouse IgG $(25 \mu \mathrm{g} / \mathrm{mL}$, ICN Pharmaceuticals Inc., Aurora, $\mathrm{OH}$ ). The other tube was left unstimulated. These 2 tubes were incubated at $39^{\circ} \mathrm{C}$ for $2 \mathrm{~h}$. All these processes were conducted aseptically. Supernatant was harvested after centrifugation, and IFN- $\gamma$ content was analyzed using an ELISA kit designed for bovine IFN- $\gamma$ determination (Bovigam, Biocor Animal Health Inc., Omaha, NE), which reports IFN- $\gamma$ concentration as optical density (O.D.) units.

\section{Statistical Analysis}

All statistical analyses were performed using SAS programs. Sampling times were divided into 2 periods, around treatment $(0 \mathrm{~d}, 24 \mathrm{~h}$, and 8 and $15 \mathrm{~d}$ after intramammary infusion) and around calving ( $-1 \mathrm{wk}, 0,8$, and $15 \mathrm{~d}$ after calving). Randomized block, factorial analyses of variances (Terranova et al., 1995), in which all comparisons were between repeated measurements taken from the same cow, were performed on the dependent variables of this study to determine the effects of treatment, time, and the treatment $\times$ time interaction. Tukey's post hoc test was also conducted to determine the difference between groups at a certain sampling time.

\section{RESULTS}

\section{General Observations}

Only 1 out of the 8 cows exhibited a rectal temperature above $39.4^{\circ} \mathrm{C}$. This cow had a high temperature of $40.6^{\circ} \mathrm{C}$ and swelling in the ZTS-treated quarters at 7 $\mathrm{h}$ after treatment. These symptoms disappeared by 24 $h$ after treatment. No other symptoms of generalized illness were observed in this cow, such as a decrease in appetite or rumen motility. No other cows exhibited any clinical symptoms of illness or discomfort. One cow developed mastitis 5 mo after calving. This occurred in a quarter in the control half udder and resolved following intramammary treatment with antibiotics for $2 \mathrm{~d}$. No other cases of mastitis were observed in these cows during the course of the experiment.

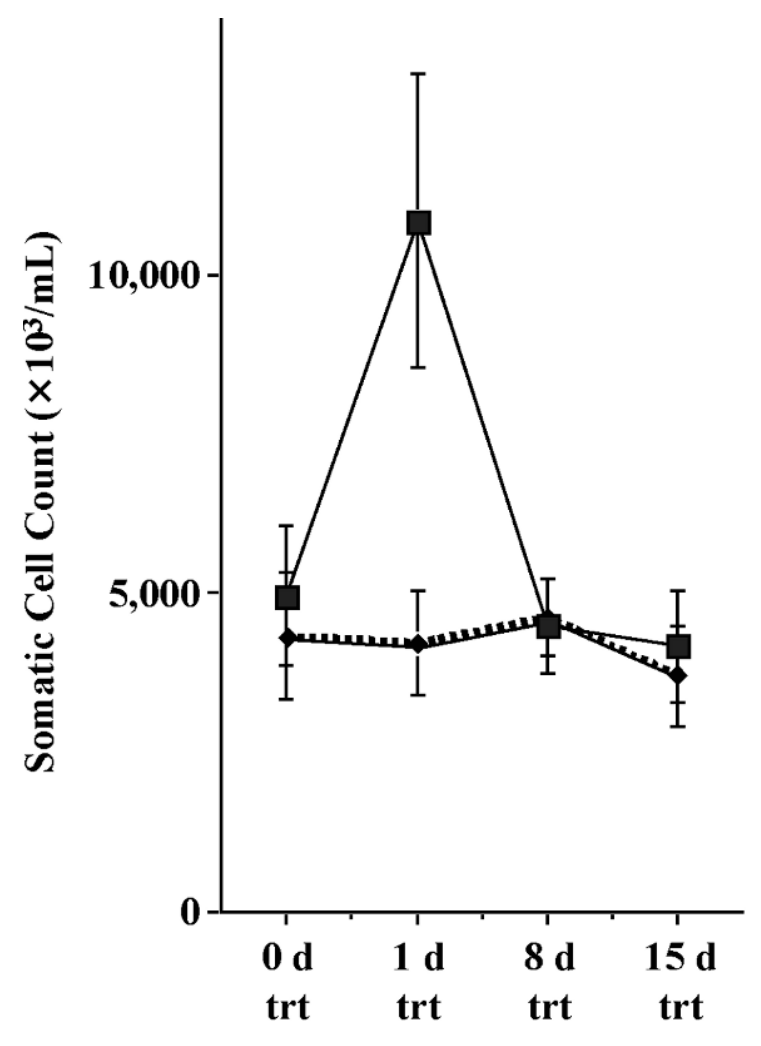

Days relative to treatment (trt)

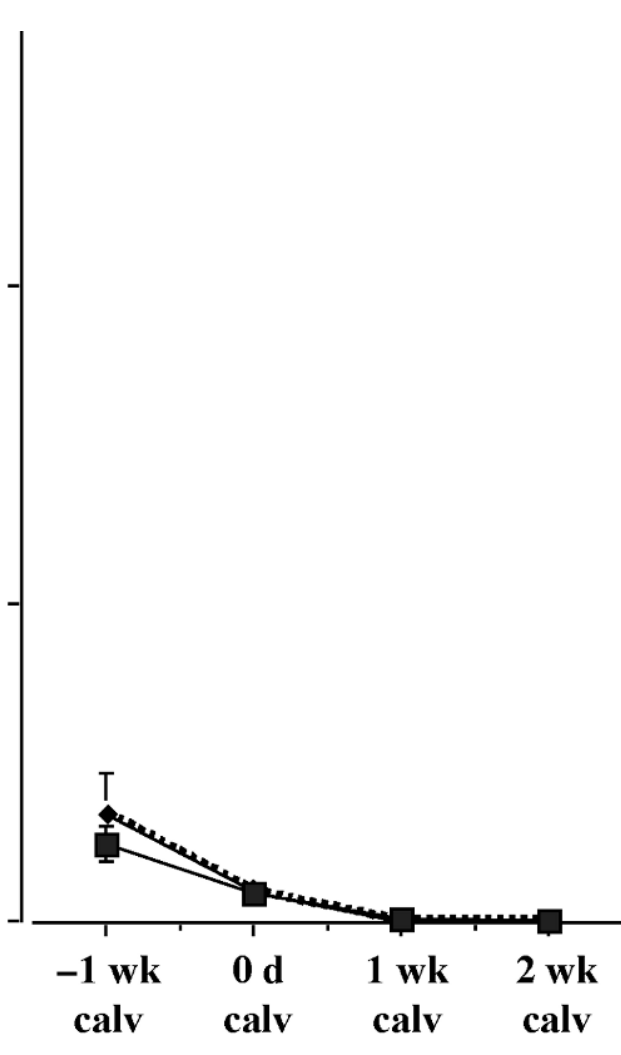

Time relative to calving (calv)

Figure 1. The changes in somatic cell count after treatment (left) and around calving (right) in zymosan-infused mammary glands $\mathrm{n}=8)$ and in saline-infused mammary glands $(\bullet, \mathrm{n}=8)$. 


\section{Bacterial Culture}

All mammary secretions collected in the course of the study were cultured, and no bacteria were ever isolated.

\section{Milk Yield}

Total milk yield for the first $15 \mathrm{~d}$ after calving in this experiment was $382.9 \pm 86.1 \mathrm{~kg} /$ head (mean $\pm \mathrm{SEM}$ ). This was higher than in these same cows in their former lactation (first lactation; $253.3 \pm 36.8 \mathrm{~kg} / \mathrm{head}$ ). Milk yield of the right (saline treated) and left (ZTS treated) halves of the udders were similar and were $187.1 \pm 48.7$ and $195.7 \pm 37.8 \mathrm{~kg} / \mathrm{head} / 15 \mathrm{~d}$, respectively, demonstrating no adverse effect of ZTS treatment on subsequent milk production.

\section{Somatic Cell Count and PMN Percentage}

The ZTS-treated quarters had significantly higher $\mathrm{SCC}$ at $24 \mathrm{~h}$ after treatment $(10,839 \pm 2,318 / \mu \mathrm{L}) \mathrm{com}$ pared with control quarters $(4,214 \pm 819 / \mu \mathrm{L})$. However, this effect was short-lived because SCC in ZTS gland milk was similar to that of control glands at all other sampling points (Figure 1). The SCC in control quarters did not change significantly around the time of treatment $(4,322 \pm 993 / \mu \mathrm{L}$ on $\mathrm{d} 0$ vs. $3,704 \pm 786 / \mu \mathrm{L}$ on $\mathrm{d}$ 15). One week before calving, SCC decreased markedly in mammary secretions $(1,214 \pm 280 / \mu \mathrm{L}$ for ZTS, 1,728 $\pm 612 / \mu \mathrm{L}$ for control) compared with SCC at the time ZTS or saline was administered. The SCC continued to decrease throughout the sampling period until the end of the experiment $(22 \pm 7 / \mu \mathrm{L}$ for ZTS, $53 \pm 24 / \mu \mathrm{L}$ for control). The PMN, as a percentage of total milk cells, exhibited a similar pattern to SCC. The percentage of PMN in ZTS quarters was significantly increased above control quarters only at $24 \mathrm{~h}$ after treatment with ZTS ( $46.8 \pm 10.4$ vs. $15.9 \pm 8.0 \%$; Figure 2$)$. Statistical analysis of SCC demonstrated significant effects of treatment $(P=0.019)$, time $(P=0.006)$, and treatment $\times$ time interaction $(P=0.001)$ during the period immediately after treatment; only the time effect significantly impacted SCC $(P=0.002)$ during the period around parturition. The PMN percentage in secretions also was significantly affected by treatment $(P=0.04)$, time $(P=$ $0.005)$, and treatment $\times$ time interaction $(P=0.019)$ during the period immediately after treatment. There were no significant differences in PMN percentage between ZTS and control quarter secretions during the period around parturition.

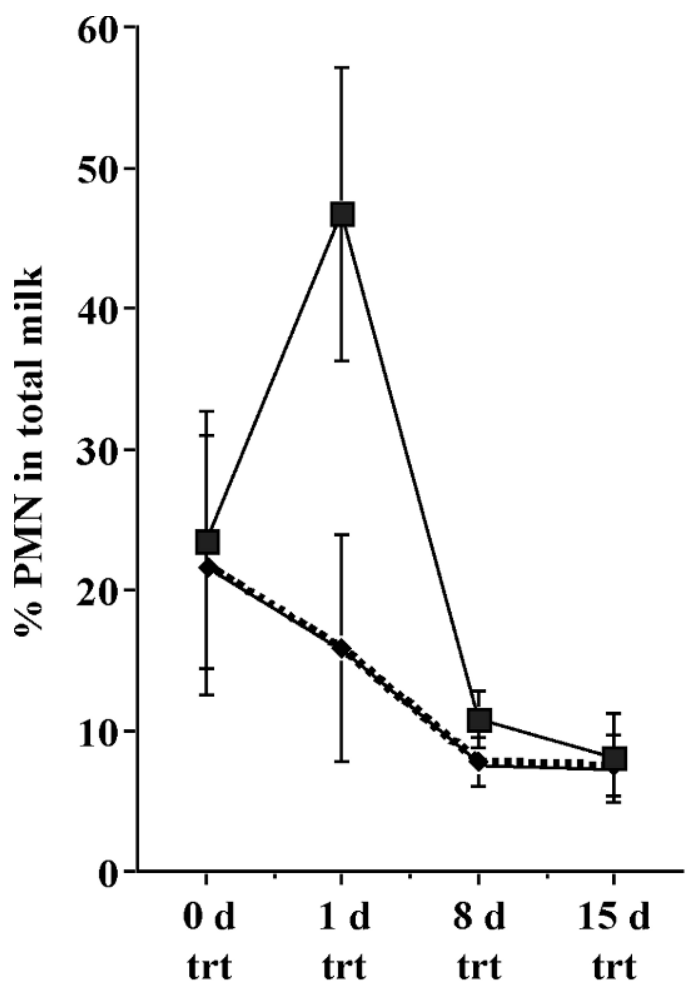

Days relative to treatment (trt)

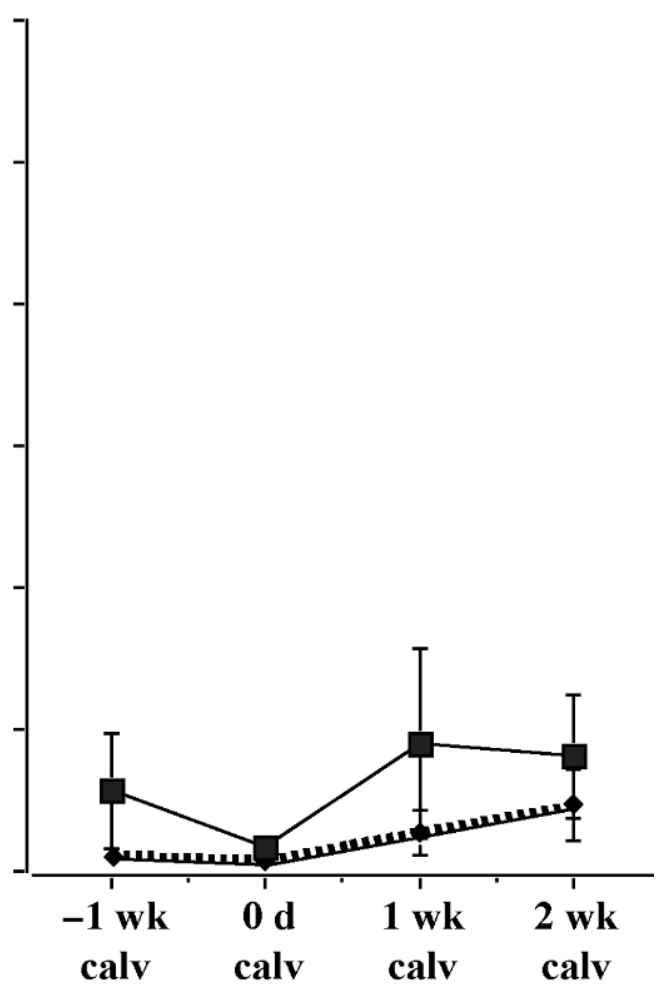

Time relative to calving (calv)

Figure 2. The percentages of polymorphonuclear neutrophils (PMN) in total cells in milk after treatment (left) and around calving (right) in zymosan-infused mammary glands $(\mathbf{\square}, \mathrm{n}=8)$ and in saline-infused mammary glands $(\bullet, \mathrm{n}=8)$. 


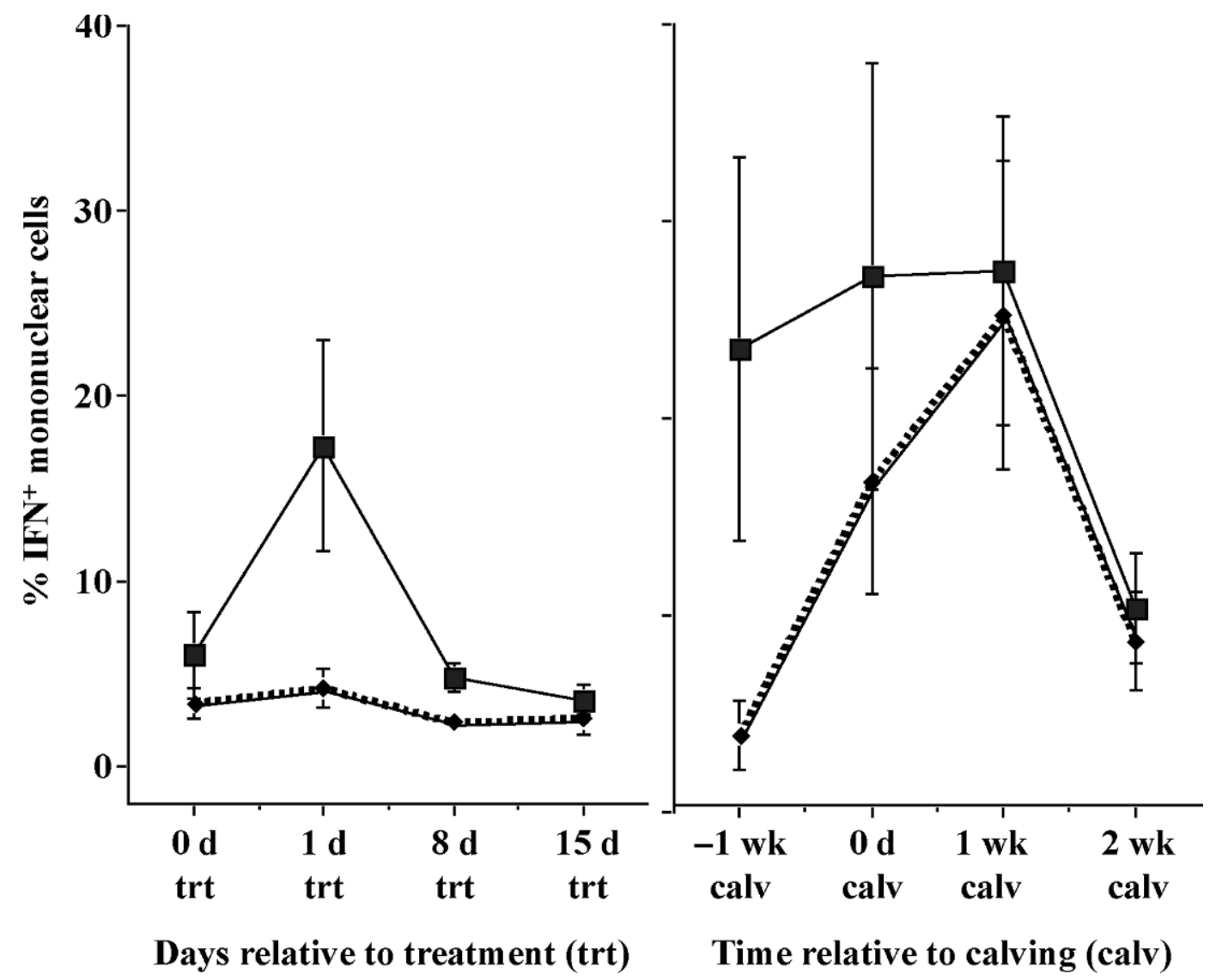

Figure 3. The percentage of IFN- $\gamma$-positive cells in total mononuclear white blood cells after treatment (left) and around calving (right) in zymosan-infused mammary glands $(\boldsymbol{\square}, \mathrm{n}=8)$ and in saline-infused mammary glands $(\bullet, \mathrm{n}=8)$.

\section{IFN- $\gamma$ Positive Cell Percentage}

The percentage of IFN- $\gamma$ positive cells in both mononuclear cells and PMN increased rapidly after treatment with ZTS (Figures 3 and 4). The increase in IFN$\gamma$ positive mononuclear cells was significant at $24 \mathrm{~h}$ $(17.3 \pm 5.7 \%$ in ZTS vs. $4.2 \pm 1.0 \%$ in control secretions, $P=0.058)$ and $8 \mathrm{~d}(4.8 \pm 0.8 \%$ in ZTS vs. $2.4 \pm 0.4 \%$ in control, $P=0.023$ ) after treatment. By $15 \mathrm{~d}$ after treatment the IFN- $\gamma$-positive mononuclear cell percentages in ZTS and control secretions were similar (Figure $3)$. A similar increase in IFN- $\gamma$-positive PMN percentage was observed during the period after treatment, and this persisted at least through the $15 \mathrm{~d}$ after treatment (Figure 4).

During the period around calving, the percentage of IFN- $\gamma$ positive mononuclear cells was higher $(P=0.087)$ in ZTS secretions $(23.5 \pm 9.7 \%)$ than in control secretions $(3.9 \pm 1.7 \%$ for control) at $1 \mathrm{wk}$ before calving. At calving the percentage of IFN- $\gamma$-positive mononuclear cells remained high in ZTS secretions. The percentage of IFN- $\gamma$-positive mononuclear cells in control secretions increased significantly from their level at $1 \mathrm{wk}$ before calving and reached a level that was similar to that seen in ZTS secretions. The percentage of IFN- $\gamma$ positive mononuclear cells remained high in secretions from all quarters the first week after calving. The percentage of IFN- $\gamma$-positive mononuclear cells decreased from that point to a similar degree in both ZTS and control quarters by 2 wk after calving. For PMN, the percentage IFN- $\gamma$-positive cells was less than $11 \%$ in both ZTS and control secretions at 1 wk before calving and the percentage IFN- $\gamma$ positive PMN increased steadily up to $1 \mathrm{wk}$ after calving in ZTS and control quarters. However, the increase in percentage of IFN$\gamma$-positive PMN in ZTS-treated quarter secretions was significantly greater than in control quarter secretions. Just as with the mononuclear cells, the percentage of IFN- $\gamma$-positive PMN was decreasing in all quarters by 2 wk after calving. Statistical analysis of data from the period around treatment showed a significant treatment $\times$ time effect $(P=0.028)$ for percentage of IFN- $\gamma$ positive mononuclear cells and a significant treatment effect for percentage of IFN- $\gamma$-positive $\operatorname{PMN}(P=0.004)$. Data from the period around calving demonstrated a 


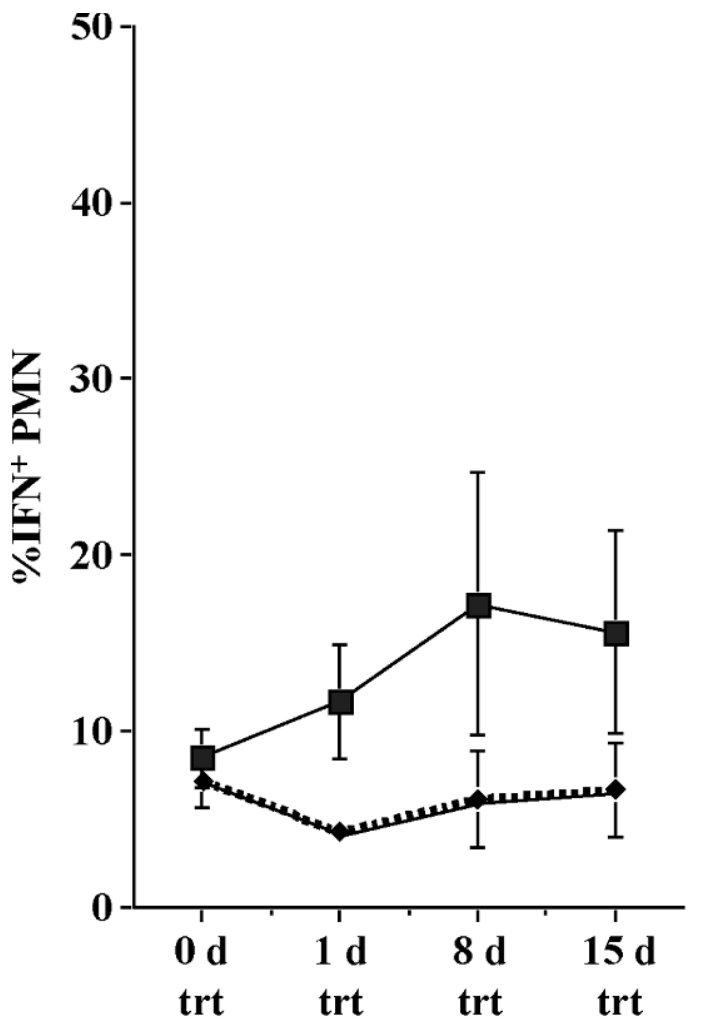

Days relative to treatment (trt)

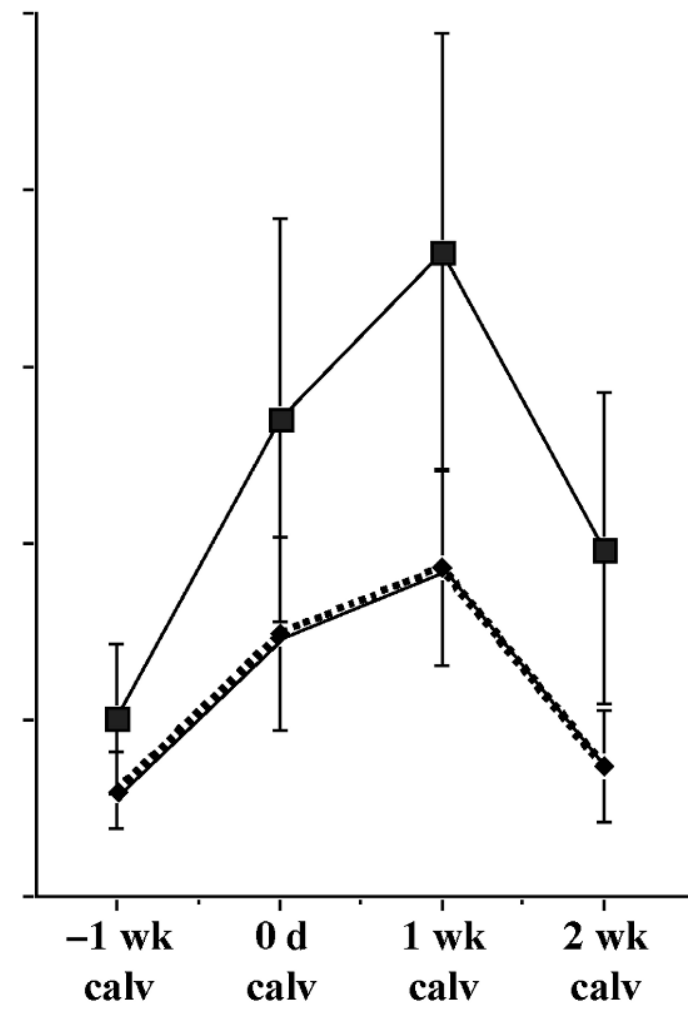

Time relative to calving (calv)

Figure 4. The percentage of IFN- $\gamma$-positive cells in polymorphonuclear neutrophils (PMN) after treatment (left) and around calving (right) in zymosan-infused mammary glands $(\boldsymbol{\square}, \mathrm{n}=8)$ and in saline-infused mammary glands $(\diamond, \mathrm{n}=8)$.

significant treatment effect for both the percentage of IFN- $\gamma$-positive mononuclear cells $(P=0.083)$ and PMN $(P=0.006)$.

The percentage of IFN- $\gamma$ positive mononuclear cells that were also T-helper lymphocytes (CD4+) is shown in Figure 5. The pattern of changes exhibited in the percentage of IFN- $\gamma$-positive T-helper cells was nearly identical to that observed for the percentage of IFN- $\gamma$ positive mononuclear cells presented in Figure 3. The T-helper lymphocytes made up between 39 to $64 \%$ of all IFN- $\gamma$-positive mononuclear cells around the time of treatment and 31 to $54 \%$ around the time of calving. Statistical analysis of the changes in the percentage of IFN- $\gamma$-positive T-helper cells demonstrated a significant time effect $(P=0.005)$ and treatment $\times$ time interaction $(P=0.024)$ during the period around treatment. A significant effect during the period around calving was observed only for treatment $(P=0.073)$.

\section{IL-8 Positive Cell Percentage}

There was a significant treatment $\times$ time effect $(P=$ 0.079 ) during the period around treatment (Figure 6).
The percentage of IL-8-positive mononuclear cells increased significantly at $24 \mathrm{~h}$ after treatment in secretions from ZTS quarters (from $2.8 \pm 1.4 \%$ to $7.8 \pm 3.5 \%$ ). During the period around calving, the percentage of IL-8-positive mononuclear cells increased in ZTS and control quarter secretions between 1 wk before and 2 wk after calving, but the pattern of the increase was somewhat different in ZTS and control secretions. There was much more variation in the control quarter secretions. During the period around calving, only the treatment $\times$ time effect significantly affected the percentage of IL-8-positive mononuclear cells $(P=0.049)$.

The percentage of IL-8-positive PMN in ZTS quarter secretions increased significantly after treatment and remained significantly elevated above the level found in control secretions during both the period after treatment $(P=0.014)$ and the period around the time of calving (treatment effect, $P=0.009$; Figure 7 ). The percentage of IL-8-positive PMN in ZTS and control secretions was elevated during the period around calving when compared with the level observed earlier in gestation. 


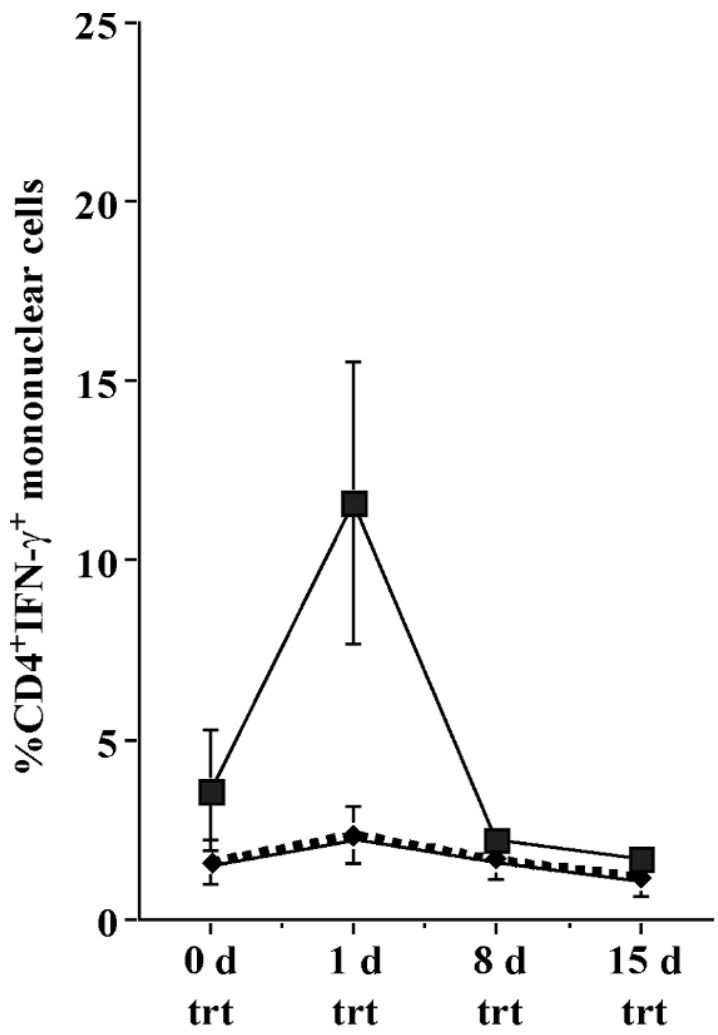

Days relative to treatment (trt)

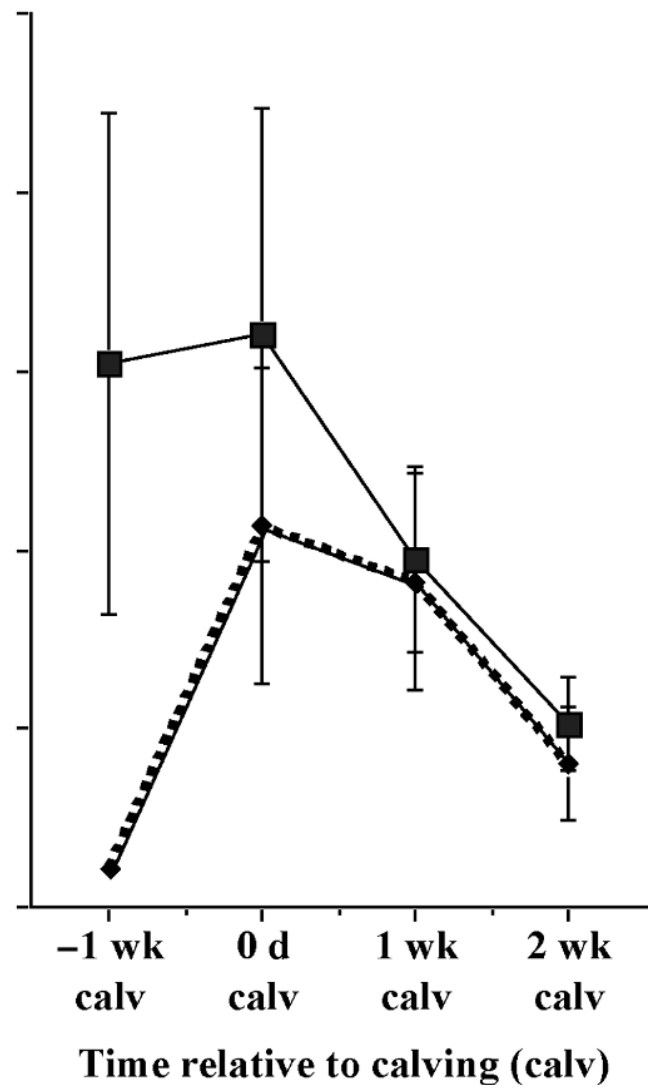

Figure 5. The percentage of IFN- $\gamma$-positive and CD4-positive cells in total mononuclear white blood cells after treatment (left) and around calving (right) in zymosan-infused mammary glands $(\mathbf{\square}, \mathrm{n}=8)$ and in saline-infused mammary glands $(\bullet, \mathrm{n}=8)$.

\section{CD4-Positive Cell Percentage in Mononuclear Cells}

There was no effect of treatment on the percentage of total mononuclear cells that were CD4-positive cells. The percentage of CD4-positive cells in the ZTS secretions during the period after treatment was between 46 and $55 \%$ and was between 48 and $55.0 \%$ in control secretions (Figure 8). The percentage of CD4-positive cells in secretions from ZTS and control quarters during the period around calving was significantly lower than the level found earlier in the dry period, but there was no difference in the percentage of CD4-positive cells in ZTS and control quarter secretions.

\section{Confirmation of IFN- $\gamma$ Production by PMN}

Polymorphonuclear neutrophils isolated from 2 healthy untreated cows were stimulated to produce cytokine by adding CD3 mAb and goat antibody against mouse IgG (this Ag-Ab complex activated complements in plasma, which then stimulated PMN) or left unstimulated, and culture supernatants were assayed for bo- vine IFN- $\gamma$ concentration by ELISA. Supernatants from stimulated PMN yielded O.D. values of 2.31 and 2.33, respectively. This is about $4.2 \mathrm{ng} / \mathrm{mL}$ according to our calibration based on recombinant bovine IFN- $\gamma$. The O.D. values of supernatants from the same PMN samples without stimulation were 0.065 and 0.12 , respectively. These results confirmed that bovine PMN were able to produce and secrete IFN- $\gamma$.

\section{DISCUSSION}

Several studies have demonstrated a reduction in IMI rate during the first week after lactation ceases when proinflammatory substances are infused into the mammary gland to incite migration of PMN into the gland and to reduce milk production and accelerate the involution of the mammary gland (Paape et al., 1976; Guidry et al., 1980; Oliver and Smith, 1982a). Few of these treatments have been studied for longer lasting effects, and the little evidence that exists suggests treatment with these compounds did not confer protection from infection beyond the early dry period. Perhaps this should not be surprising because PMN are rela- 


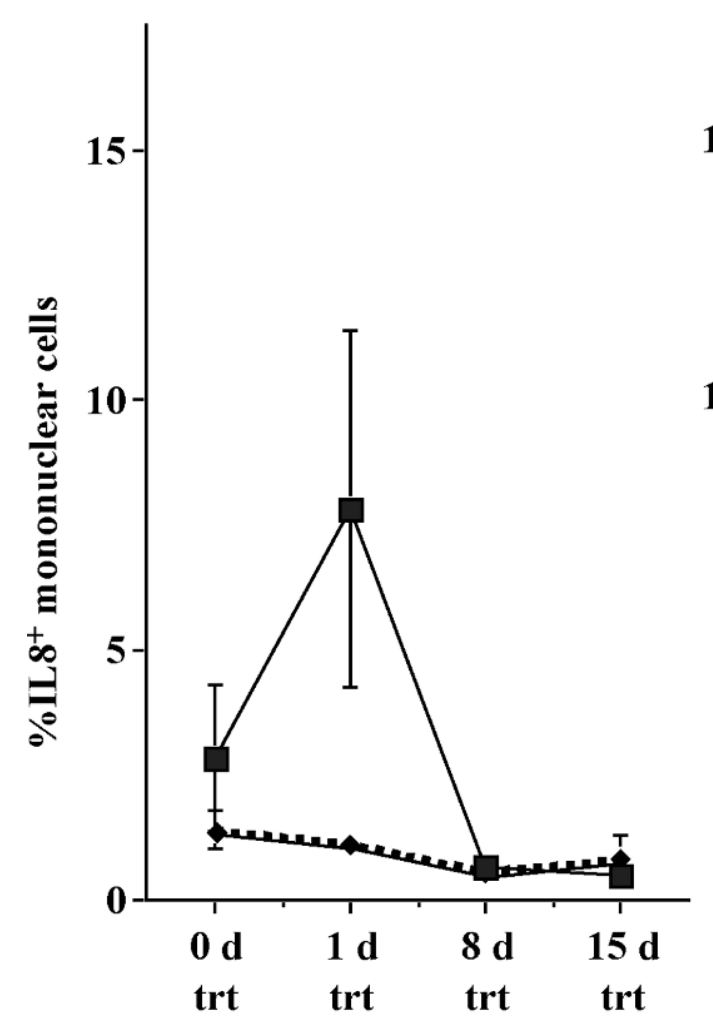

Days relative to treatment (trt)

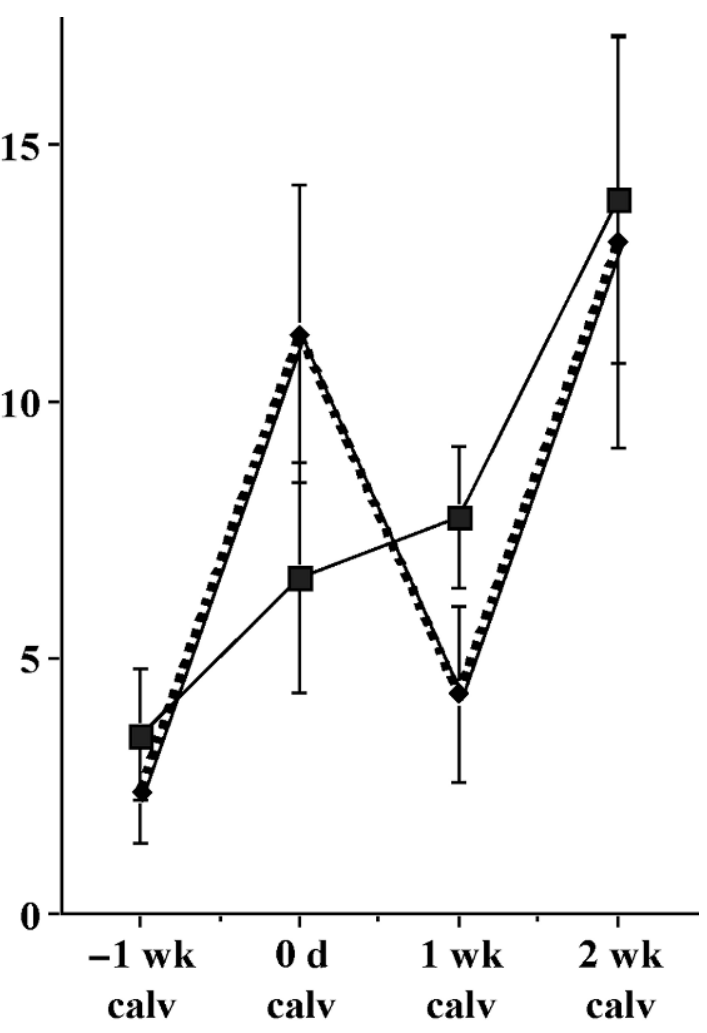

Time relative to calving (calv)

Figure 6. The percentage of IL-8-positive cells in total mononuclear white blood cells after treatment (left) and around calving (right) in zymosan-infused mammary glands $(\mathbf{\square}, \mathrm{n}=8)$ and in saline-infused mammary glands $(\bullet, \mathrm{n}=8)$.

tively short-lived cells and once the stimulus for their migration is removed the effect will not persist.

However, an agent capable of seeding the mammary gland with competent leukocytes, especially lymphocytes, could enhance resistance of cows to IMI. Phytohemagglutinin A and concanavalin A have also been successfully used to accelerate involution of the mammary gland at dry off (Breau and Oliver, 1985, 1986). These plant lectins have the added benefit of being nonspecific mitogens, which could induce activation of lymphocytes. Lymphocyte populations were not directly examined in these studies. However, when these plant lectins were infused into cows at dry-off, the secretions obtained from the cows were higher in immunoglobulin and inhibited growth of Klebsiella pneumoniae, Escherichia coli, and Streptococcus uberis better than secretions from untreated quarters. The greatest inhibition of bacterial growth was observed in secretions obtained $7 \mathrm{~d}$ before calving, suggesting a benefit of greater duration than when LPS was infused at dry-off. Unfortunately, at the time of calving there was a marked reduction in the ability of the mammary secretions to inhibit bacterial growth in both lectin-treated and control quar- ters (Breau and Oliver, 1986). Infusion of LPS or endotoxins rapidly increases PMN migration into the mammary gland. It is unclear whether recruitment of these PMN confers resistance against mastitis pathogens because in one study, growth of all mastitis pathogens evaluated was similar in cell-free fat-free mammary secretions obtained during early dry-off from LPS-infused and control glands (Oliver, 1991).

The ZTS is a source of C5a, the most biologically potent activator and chemoattractant for PMN (Rainard et al., 1998), and recruitment of PMN into the teat canal can occur in as little as $1.5 \mathrm{~h}$ following C5a infusion (Persson et al., 1993). A rapid increase in C5a concentrations and other inflammatory cytokines in mammary secretions during the early stages of infection of the mammary gland is associated with elimination of bacteria from the gland, presumably by recruiting PMN to the mammary gland and activating the PMN in the mammary gland (Shuster et al., 1997; Riollet et al., 2000). Unfortunately, the C5a present in nonmastitic milk is usually not sufficient to allow eradication of bacteria early in the course of an infection (Rainard, 2003). Infusion of C5a, in the crude form of ZTS, 


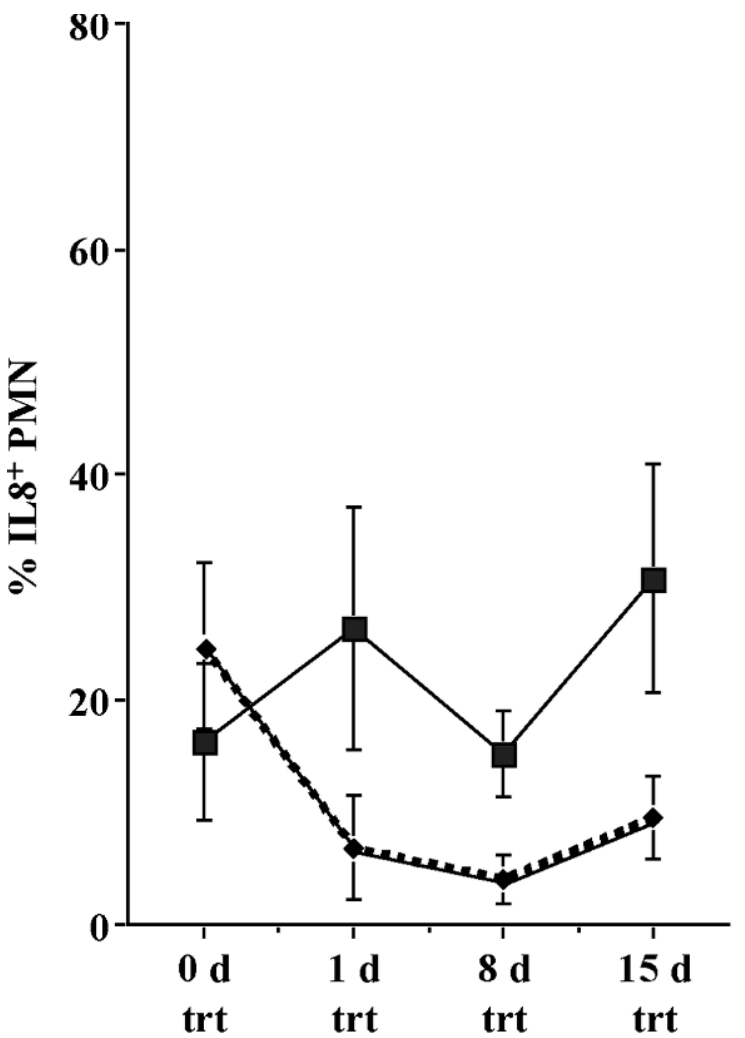

Days relative to treatment (trt)

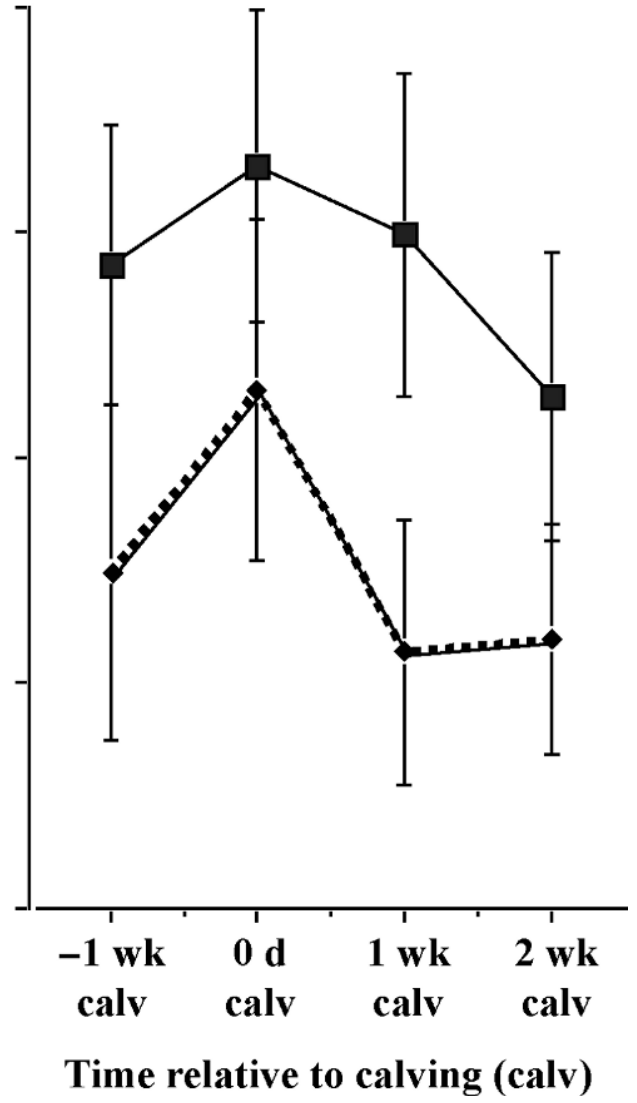

Figure 7. The percentage of IL-8-positive cells in polymorphonuclear neutrophils (PMN) after treatment (left) and around calving (right) in zymosan-infused mammary glands $(\boldsymbol{\square}, \mathrm{n}=8)$ and in saline-infused mammary glands $(\bullet, \mathrm{n}=8)$.

did effectively recruit PMN into the nonlactating mammary gland for several days after infusion. Perhaps more importantly the PMN that were recruited by ZTS were in a higher state of activation, with more of them producing IFN- $\gamma$ and IL-8 than PMN found in salineinfused quarter secretions. Surprisingly, PMN around the time of calving continued to be in a higher state of activation in ZTS-infused quarters than in saline treated quarters. The half-life of circulating PMN is only 6 to $10 \mathrm{~h}$ after being released from the bone marrow (Coxon et al., 1999). The life span of activated PMN migrated into tissue can be longer, but they do not live beyond a week (Scheel-Toellner et al., 2004). The sustained activation status of PMN in mammary gland secretion observed in this experiment may be due to the presence of activated lymphocytes or epithelial cells in mammary glands. These activated cells can live long and secrete cytokines. They may have recruited/activated PMN in mammary glands around the time of calving. Several studies have indicated that sensitized lymphocytes can recruit/activate PMN, and the presence of T cells can influence PMN function (Campbell, 1990; Herbelin et al., 1997). In this study we unfortu- nately did not analyze cells in mammary tissue and cytokines in mammary gland secretions. It is already known that mammary gland epithelial cells are an important source of cytokines (Okada et al., 1997). Activated cells can reside in tissue, without being released into milk. These tissue residing activated cells may have contributed to the sustained increase in IFN- $\gamma$ and IL-8-positive cell populations. Whether ZTS can activate mammary gland epithelial cells expressing C5a receptor remains unknown. The presence of C5a receptor on epithelial cells in lung and liver has been demonstrated (Riedemann et al., 2002; Strey et al., 2003). The PMN in control quarter secretions were producing more IL-8 during the time around calving than in the earlier part of the dry period. Colostrum contains various cytokines such as IL- $1 \beta$, IL-6, TNF- $\alpha$, and IFN- $\gamma$, and their presence is thought to provide some protection to calves (Hagiwara et al., 2000). The sources of these cytokines are epithelial cells or immune cells present in mammary glands. There may be certain activation processes in mammary glands just before calving that increase cytokine production. This activation process may be responsible for the increased percentage 


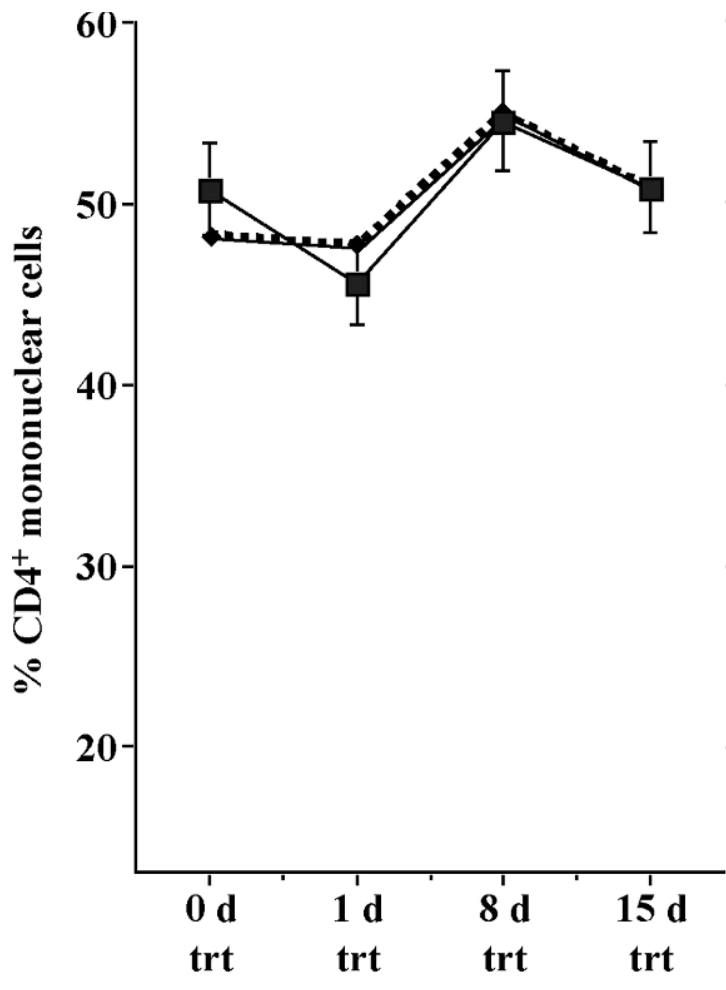

Days relative to treatment (trt)

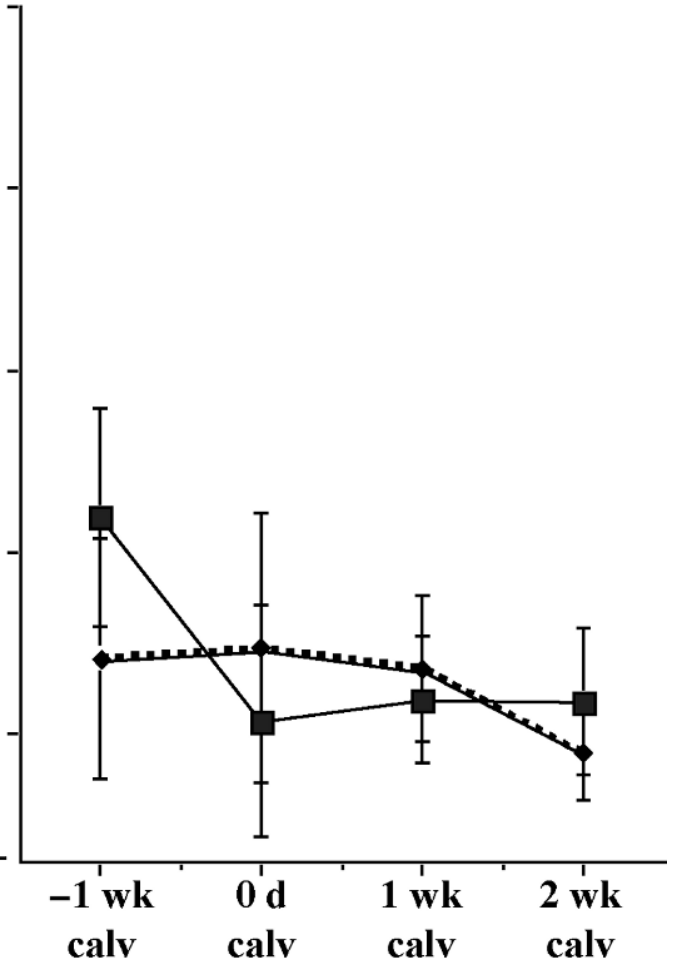

Time relative to calving (calv)

Figure 8. The percentage of CD4-positive cells in total mononuclear white blood cells after treatment (left) and around calving (right) in zymosan-infused mammary glands $(\square, n=8)$ and in saline-infused mammary glands $(\bullet, \mathrm{n}=8)$.

of IFN- $\gamma$ - and IL-8-positive cells in milk in control and ZTS quarters around the time of calving. The activated PMN and mononuclear cells in colostrum may not be sufficient to prevent mastitis completely, judging from the high incidence of mastitis in the early stage of lactation. Other factors involved in periparturient immunosuppression also likely contribute to the high incidence of mastitis. The ZTS infusion, however, can increase the number of activated immune cells compared with control; thus it may help prevent mastitis. The T- and natural killer lymphocytes are the traditional sources of the cytokine IFN- $\gamma$. The IFN- $\gamma$ stimulates the respiratory burst and lysosomal activities of PMN, enhancing their bactericidal activity. It also promotes antibodydependent cell-mediated cytotoxicity by PMN. The IFN$\gamma$ inhibits macrophage migration, and increases expression of major histocompatibility complex (MHC) antigens and $\mathrm{Fc} \gamma$ receptors on macrophages, promoting antibody mediated phagocytosis. The IFN- $\gamma$ increases activity of natural killer cells and induces production of interleukin-2 and its receptor on T-lymphocytes. The IFN- $\gamma$ causes antibody isotype shifts in B-lymphocytes toward $\mathrm{IgG}_{2 \mathrm{a}}$, which may promote antigen agglutination. The IFN- $\gamma$ upregulates MHC-I (Garibay-Escobar et al., 2003; Sikorski et al., 2004) and MHC-II, even on PMN (Ellis and Beaman, 2004). Because ZTS infusion increased the number of IFN- $\gamma$-positive cells, it seems likely that ZTS infusion caused the production of effector/memory cells within the mammary tissues.

We also found that bovine PMN can produce IFN$\gamma$. It is confirmed by measuring secreted IFN- $\gamma$ from isolated PMN after stimulation using ELISA specific to bovine IFN- $\gamma$. Nonstimulated PMN did not have detectable secreted IFN- $\gamma$ in this assay (data not shown). Thus, in addition to the direct action of the C5a in ZTS on activation of lymphocytes, infusion of ZTS activated the PMN to secrete IFN- $\gamma$ and IL-8, which also should have stimulated further lymphocyte activity indirectly (Tsuji et al., 1997; Nielsen and Leslie, 2002). Human and mouse PMN are known to produce IFN- $\gamma$ (Yeaman et al., 1998; Ellis and Beaman, 2002; Venuprasad et al., 2002). Production of IFN- $\gamma$ by PMN seemed critical to elimination of Leishmania and Nocardia infection in these studies. Recently the production of IFN- $\gamma$ as well as TNF- $\alpha$, IL-1 $\beta$, IL-12, and IL- 8 by bovine PMN activated by LPS has been reported (Sohn et al., 2007). This report also confirmed the ability of PMN to be 
involved in the activation of other immune cells by secreting cytokines.

Recruitment of PMN and other leukocytes and enhancement of their phagocytic and bactericidal activities during the early portion of the dry period could help protect the cow from bacterial infection during the critical period of mammary gland involution. In this study infusion of C5a, in the form of ZTS, had longlasting effects, including maintenance of higher populations of activated lymphocytes and PMN during the period around the time of parturition, suggesting that ZTS treatment successfully seeded the mammary tissues with cells capable of mounting a vigorous response to an invading pathogen. It did this without causing untoward side effects such as inappetence and had no long-term effects on milk production in infused quarters. Further studies will be needed to determine if ZTS treatment at the time of dry off or shortly after dryoff can successfully reduce new IMI rate during the periparturient period of the cow.

\section{CONCLUSIONS}

The ZTS infusion into nonlactating mammary glands increased the number of activated PMN and mononuclear cells in mammary secretions as determined by the presence of intracellular IFN- $\gamma$ and IL-8. These cells remained in a heightened state of activation through the first week of lactation. The ZTS stimulated responses by PMN and mononuclear cells occur very quickly after infusion, which could increase resistance to bacterial infection in the early dry period. The ZTS infusion increased the activity of mononuclear cells residing within the mammary tissues or extravasating from the circulation from the time of treatment through the first week of lactation. This may represent a state of higher readiness in these cells, so that when they encounter a bacterial antigen around the time of calving they will respond without delay, which could reduce the rate of IMI during this period of the cow's life.

\section{ACKNOWLEDGMENTS}

The authors are thankful for the great help of Arlen Anderson in sampling cows and bacterial culture; and Norm Tjelmeland, Creig Caruth, and Andrew Moser (NADC, USDA/ARS, Ames, IA) for their excellent care of animals. Great appreciation goes to Pascal Rainard (INRA, France) for assay of C5a and Robert Strahan (Iowa State Univ., Ames) for programming of statistical analysis.

\section{REFERENCES}

Bensaid, A., and M. Hadam. 1991. Individual antigens of cattle. Bovine CD4 (BoCD4). Vet. Immunol. Immnopathol. 27:51-54.
Breau, W. C., and S. P. Oliver. 1985. Accelerated bovine mammary involution induced by infusion of concanavalin A or phytohemagglutinin. Am. J. Vet. Res. 46:816-820.

Breau, W. C., and S. P. Oliver. 1986. Growth inhibition of environmental mastitis pathogens during physiologic transitions of the bovine mammary gland. Am. J. Vet. Res. 47:218-222.

Campbell, P. A. 1990. The neutrophil, a professional killer of bacteria, may be controlled by T cells. Clin. Exp. Immunol. 79:141-143.

Comalli, M. P., R. J. Eberhart, L. C. Griel, Jr., and H. Rothenbacher. 1984. Changes in the microscopic anatomy of the bovine teat canal during mammary involution. Am. J. Vet. Res. 45:22362242 .

Cousins, C. L., T. M. Higgs, E. R. Jackson, F. K. Neave, and F. H. Dodd. 1980. Susceptibility of the bovine udder to bacterial infection in the dry period. J. Dairy Sci. 47:11-18.

Coxon, A., T. Tang, and T. N. Mayadas. 1999. Cytokine-activated endothelial cells delay neutrophil apoptosis in vitro and in vivo: A role for granulocyte/macrophage colony-stimulating factor. J. Exp. Med. 190:923-933.

Davis, W. C., S. Marusic, H. A. Lewin, G. A. Splitter, L. E. Perryman, T. C. McGuire, and J. R. Gorham. 1987. The development and analysis of species specific and cross reactive monoclonal antibodies to leukocyte differentiation antigens and antigens of the major histocompatibility complex for use in the study of the immune system in cattle and other species. Vet. Immunol. Immunopathol. 15:337-376.

Ellis, T. N., and B. L. Beaman. 2002. Murine polymorphonuclear neutrophils produce interferon- $\gamma$ in response to pulmonary infection with Nocardia asteroides. J. Leuk. Biol. 72:373-381.

Ellis, T. N., and B. L. Beaman. 2004. Interferon- $\gamma$ activation of polymorphonuclear neutrophils function. Immunobiol. 112:2-12.

Garibay-Escobar, A., I. Estrada-Garcia, S. Estrada-Parra, and L. Santos-Argumedo. 2003. Integrated measurements by flow cytometry of the cytokines IL-2, IFN- $\gamma$, IL-12, TNF- $\alpha$ and functional evaluation of their receptors in human blood. J. Immunol. Metho. 280:73-88.

Guidry, A. J., M. J. Paape, and R. E. Pearson. 1980. Effect of udder inflammation on milk immunoglobulins and phagocytes. Am. J. Vet. Res. 41:751-753.

Hagiwara, K., S. Kataoka, H. Yamanaka, R. Kirisawa, and H. Iwai. 2000. Detection of cytokines in bovine colostrum. Vet. Immunol. Immunopathol. 76:183-190.

Herbelin, C., B. Poutrel, F. B. Gilbert, and P. Rainard. 1997. Immune recruitment and bactericidal activity of neutrophils in milk of cows vaccinated with Staphylococcal a-toxin. J. Dairy Sci. 80:2025-2034.

Morgan, E. L., M. L. Thoman, W. O. Weigle, and T. E. Hugli. 1983. Anaphylatoxin-mediated regulation of the immune response II. C5a-mediated enhancement of human humoral and T cell-mediated immune responses. J. Immunol. 130:1257-1261.

Nickerson, S. C. 1989. Immunological aspects of mammary involution. J. Dairy Sci. 72:1665-1678.

Nielsen, C. H., and R. G. Q. Leslie. 2002. Complement's participation in acquired immunity. J. Leuk. Biol. 72:249-261.

Okada, H., T. Ito, H. Ohtsuka, R. Kirisawa, H. Iwai, K. Yamashita T. Yoshino, and T. J. Rosol. 1997. Detection of interleukin-1 and interleukin- 6 on cryopreserved bovine mammary epithelial cells in vitro. J. Vet. Med. Sci. 59:503-507.

Oliver, S. P. 1991. Growth of Staphylococcus aureus and Streptococcus species in bovine mammary secretions during the nonlactating and peripartum periods following intramammary infusion of lipopolysaccharide at cessation of milking. Zentralbl. Veterinarmed. B. 38:538-544.

Oliver, S. P., and K. L. Smith. 1982a. Bovine mammary involution following intramammary infusion of colchicine and endotoxin at drying off. J. Dairy Sci. 65:801-813.

Oliver, S. P., and K. L. Smith. 1982b. Milk yield and secretion composition following intramammary infusion of colchicine. J. Dairy Sci. 65:204-210.

Oliver, S. P., and K. L. Smith. 1982c. Nonantibiotic approach in control of bovine mastitis during dry period. J. Dairy Sci. 65:2119-2124. 
Paape, M. J., R. E. Pearson, W. P. Wergin, and A. J. Guidry. 1976. Enhancement of chemotactic response of polymorphonuclear leukocytes into the mammary gland and isolation from milk. J. Dairy Sci. 60:53-63.

Paape, M. J., K. Shafer-Weaver, A. V. Capuco, K. Van Oostveldt, and C. Burvenich. 2000. Immune surveillance of mammary tissue by phagocytic cells. Adv. Exp. Med. Biol. 480:259-277.

Persson, K., I. Larsson, and C. H. Sandgren. 1993. Effects of certain inflammatory mediators on bovine neutrophil migration in vivo and in vitro. Vet. Immunol. Immunopathol. 37:99-112.

Rainard, P. 2003. The complement in milk and defense of the bovine mammary gland against infections. Vet. Res. 34:647-670.

Rainard, P., P. Sarradin, M. J. Paape, and B. Poutrel. 1998. Quantification of $\mathrm{C} 5 \mathrm{a} / \mathrm{C} 5 \mathrm{a}$ (des-Arg) in bovine plasma, serum and milk. Vet. Res. 29:73-88.

Riedemann, N. C., R.-F. Guo, V. J. Sarma, I. J. Laudes, M. HuberLang, R. L. Warner, E. A. Albrecht, C. L. Speyer, and P. A. Ward. 2002. Expression and function of the C5a receptor in rat alveolar epithelial cells. J. Immunol. 168:1919-1925.

Riollet, C., P. Rainard, and B. Poutrel. 2000. Differential induction of complement fragment C5a and inflammatory cytokines during intramammary infections with Escherichia coli and Staphylococcus aureus. Clin. Diagn. Lab. Immunol. 7:161-167.

Roth, J. A., and M. L. Kaeberle. 1981. Evaluation of bovine polymorphonuclear leukocyte function. Vet. Immunol. Immunopathol. 2:157-174.

Sager, H., W. C. Davis, D. A. Dobbelaere, and T. W. Jungi. 1997. Macrophage-parasite relationship in theileriosis. Reversible phenotypic and functional dedifferentiation of macrophages infected with Theileria annulata. J. Leuk. Biol. 61:459-468.

Sanderson, S. D., S. R. Cheruku, M. P. Padmanilayam, J. L. Vennerstrom, G. M. Thiele, M. I. Palmatier, and R. A. Bevins. 2003. Immunization to nicotine with a peptide-based vaccine composed of a conformationally biased agonist of C5a as a molecular adjuvant. Int. Immunopathol. 3:137-146.

Scheel-Toellner, D., K. Wang, R. Craddock, P. R. Webb, H. M. McGettrick, L. K. Assi, N. Parkes, L. E. Clough, E. Gulbins, M. Salmon, and J. M. Lord. 2004. Reactive oxygen species limit neutrophil life span by activating death receptor signaling. Blood 104:2557-2564

Schultze, W. D., and M. J. Paape. 1983. Effect on outcome of intramammary challenge exposure with Staphylococcus aureus of so- matic cell concentration and presence of an intramammary device. Am. J. Vet. Res. 45:420-423.

Shuster, D. E., M. E. Kehrli, Jr., P. Rainard, and M. Paape. 1997. Complement fragment C5a and inflammatory cytokines in neutrophil recruitment during intramammary infection with Escherichia coli. Infect. Immun. 65:3286-3292.

Sikorski, M., M. Bobek, H. Zrubek, and J. Marcinkiewicz. 2004. Dynamics of selected MHC class I and II molecule expression in the course of HPV positive CIN treatment with the use of human recombinant IFN-gamma. Acta Obstet. Gynecol. Scand. 83:299-307.

Smith, K. L., D. A. Todhunter, and P. S. Schoenberger. 1985. Environmental pathogens and intramammary infection during the dry period. J. Dairy Sci. 68:402-417.

Sohn, E., M. Paape, E. Connor, D. Bannerman, R. Fetterer, and R. Peters. 2007. Bacterial lipopolysaccharide stimulates bovine neutrophil production of TNF-alpha, IL-1beta, IL-12 and IFNgamma. Vet. Res. 38:809-818.

Strey, C. W., M. Markiewski, D. Mastellos, R. Tudoran, L. A. Spruce, L. E. Greenbaum, and J. D. Lambris. 2003. The proinflammatory mediators C3a and C5a area essential for liver regeneration. J. Exp. Med. 198:913-923.

Terranova, P. F., V. J. Hunter, K. F. Roby, and J. S. Hunt. 1995. Tumor necrosis factor-a in the female reproductive tract. Proc. Soc. Exp. Biol. Med. 209:325-342.

Tsuji, R. F., G. P. Geba, Y. Wang, K. Kawamoto, L. A. Matis, and P. W. Askenase. 1997. Required early complement activation in contact sensitivity with generation of local C5-dependent chemotactic activity, and late T cell interferon $\gamma$ : A possible initiating role of B cells. J. Exp. Med. 186:1015-1026.

Ulrich, J. T., W. Cieplak, N. J. Paczkowski, S. M. Taylor, and S. D. Sanderson. 2000. Induction of an antigen-specific CTL response by a conformationally biased agonist of human C5a anaphylatoxin as a molecular adjuvant. J. Immunol. 164:5492-5498.

Venuprasad, K., P. P. Banerjee, S. Chattopadhyay, S. Sharma, S. Pal, P. B. Parab, D. Mitra, and B. Saha. 2002. Human neutrophilexpressed CD28 interacts with macrophage B7 to induce phosphatidylinositol 3-kinase-dependent IFN- $\gamma$ secretion and restriction of Leishmania growth. J. Immunol. 169:920-928.

Yeaman, G. R., J. E. Collins, J. K. Currie, P. M. Guyre, C. R. Wira, and M. W. Fanger. 1998. IFN- $\gamma$ is produced by polymorphonuclear neutrophils in human uterine endometrium and by cultured peripheral blood polymorphonuclear neutrophils. J. Immunol. 160:5145-5153. 